\title{
The food spectrum of the cardinal - tetra (Paracheirodon axelrodi, Characidae) in its natural habitat.
}

\author{
Ilse WALKER ${ }^{1}$
}

\begin{abstract}
The cardinal tetra (Paracheirodon axelrodi) is the most intensively commercialized ornamental fish from the Rio Negro Basin (Amazonas State, Brasil). Analysis of the stomach and gut contents of fish caught in their natural habitats show conclusively that the cardinal is essentially a predator, feeding on the mesofauna that adheres to submerged litter, roots and waterplants. Microcrustacea and chironomid larvae (Diptera) were the most frequently ingested prey, while algae intake was relatively infrequent. It is argued that the relatively small size of the cardinals captured in their natural habitat is due to the annual migrations imposed by the inundation cycles, rather than to resource limitation, because it is known from earlier investigations of similar habitats, that these plant substrates are densely colonized by the aquatic mesofauna. Cardinals raised in captivity are larger and have higher rates of growth.
\end{abstract}

\section{KEY WORDS}

Rio Negro, cardinal, diet.

\section{Estratégias alimentares do cardinal-tetra (Paracheirodon axelrodi, Characidae) em seu ambiente natural.}

\begin{abstract}
RESUMO
O cardinal (Paracheirodon axelrodi) é o peixe ornamental comercializado com maior intensidade na Bacia do Rio Negro (Estado do Amazonas, Brasil). Análise do conteúdo estomacal de peixes capturados nos seus habitats naturais mostra, que o cardinal é essencialmente um predador, alimentando-se da mesofauna que está colonizando a liteira submersa, arbustos submersos, raizes flutuantes e plantas aquáticas. As presas principais são microcrustáceos e larvas de quironomídeos (Chironomidae, Diptera), enquanto ingestão de algas é pouco freqüente. Considera-se que o tamanho relativamente pequeno de cardinais capturados nos ambientes naturais é devido as migrações anuais que acompanham os ciclos anuais de enchente e vazante, e não à falta de recursos; já que é conbecido de ambientes parecidos de outros rios da região, que estes substratos aquáticos são densamente colonizados pela mesofauna. Cardinais criados em cativeiros tem taxas de crescimento mais altas e são de tamanbo maiores
\end{abstract}

PALAVRAS-CHAVE

Rio Negro, cardinal, dieta

\section{INTRODUCTION}

The "Néon Tetra" or "Cardinal Tetra" or simply the "Cardinal " (Tetragonopertinae, Characidae) is the most intensively commercialized ornamental fish of the Amazon State. (Brasil). Its area of distribution is the middle Rio Negro Basin, particularly its many tributaries and their smaller affluents (igarapés), forest lakes and, during the annual periods of inundation, the lowland forest itself, the "igapó". Some 12-15 million neon-tetras are exported annually, this is ca $80 \%$ of the total market of ornamental fish of the Amazon State (Chao 2001). This situation led to the fear that the species may be doomed to extinction (Bayley and Petrere 1990). For this reason, a project was mounted in
1989 by the University of the Amazonas (FUA) and the National Institute of Amazon Research (INPA, Manaus, Amazonas) with the objective to investigate the biology and ecology of the ornamental fish, and to establish guidelines for sustainable exploitation ("Projeto Piaba"; piaba = local name for small tetragonopterine fish).

Although famous the world over as an aquarium fish, the natural biology of Paracheirodon axelrodi is still not well known, indeed, not even its systematic status is well established, new species and/or varieties keep appearing in the collections (Géry, 1977; Weitzman and Fink 1987; Petry 1999 per. com.).

In Sept/Oct 1999, I participated in one of the excursions organized by the project, and thanks to the efforts of crew and collegues (Drs. P. Petry and N.L. Chao),

${ }^{1}$ Department of Ecology (CPEC) Instituto Nacional de Pesquisas da Amazônia (INPA), C.P. 478; 69.011-970 Manaus (AM), Brasil. e-mail: iwalker@inpa.gov.br 


\section{ACTA \\ AMAZONICA}

THE FOOD SPECTRUM OF THE CARDINAL - TETRA

(Paracheirodon axelrodi, CHARACIDAE) IN ITS NATURAL HABITAT.
I could actually observe the neon-tetra in its natural habitat. For, despite its high frequency in the area, the habitats are of very difficult access, one has to row and motor for hours through narrowest waterways in dense understory vegetation. Indeed, it is probably this condition of wide distribution (several thousand $\mathrm{km}^{2}$ ) and difficult access that allowed for the hitherto undiminished rate of commercialization.

One of the unknowns of the cardinal is its feeding habits. Its biotopes include areas of low flow velocities, shallow waters with- light permitting- the presence of water plants, the litter-covered bottoms of streams and rivers, and the forest floor during the months of inundation (March/April to July/Aug; Geisler and Annibal 1984). The fish move about in groups of a few dozen and browse between roots and waterplants and over the submerged litter leaves, presumably scraping periphyton. Owing to the notorius mineral poverty of the Rio Negro drainage basin (Sioli, 1984), resource supplies are supposed to be limiting for the growth of the cardinal (Geisler and Annibal, 1984).

As I worked for many years on the trophic structure of the aquatic ecosystems of the these poor waters (Walker, 1987; 1988), I welcomed the opportunity to analyse the gut content of a series of $P$. axelrodi, which were collected between July and October 1999 by Dr. P. Petry, then curator of INPA's fish collection. As the sampling sites include 14 different rivers and streams over a range of some $450 \mathrm{~km}$ along the middle Rio Negro, the results seem to be noteworthy, despite the small number of fish that were available for dissection from each river.

\section{MATERIAL AND METHODS}

\section{Areas of collection}

All fish were collected in the basins of the large rivers that join the Rio Negro westward, that is, up-river, from the city of Barcelos (Table 1). The collection sites were the channels of small tributary streams (igarapés), the inundated forest floor along the stream valley bottoms and permanetly inundated areas with dense, shrub-like vegetation, all situated within undisturbed, primary forest ecosystems. The samples were taken between July and October 1999, i.e. during the period of falling water levels of the annual inudation cycle (JulyNovember). This is the post-reproductive period of $P$. axelrodi, which spawns during the early phase of rising waters, form February to April (Geisler and Annibal, 1984).

Limnological conditions: The $\mathrm{pH}$-values of all collection sites ranged between 3,35 and 5,82, this last value referring to the Rio Demini, and being the only value of $\mathrm{pH}>5.0$. The range of conductivity was $8.03 \mu \mathrm{S}_{20} / \mathrm{cm}$ (Rio Caurés) to 22.8 (Igarapé Arixaná).

\section{Methods}

Collections were carried out by handnet. As the cardinal moves in small schools, a single net sample often yielded several fish. The specimens separated for dissection were immediatly transferred into $10 \%$ formol or $70 \%$ alcohol, in order to stop digestion and to increase the chance to identify the food items.

Dissection: In the laboratory, the fish were cut open with ophtalmological scissors by a ventral, longitudinal

Table 1 - Number of fish ( $\mathrm{N}^{\mathrm{o}}$ ) in different size classes (standard length in $\mathrm{mm}$ ), collected in different rivers (R) or in their smaller tributaries (Ig = Igarapé for stream). N/S = northern or southern tributaries, respectively, of the Rio Negro. GPS = geographic position as determined by the Global Position Systems. * Includes a single fish of $28 \mathrm{~mm}$. ** Barragem = dam.

\begin{tabular}{|c|c|c|c|c|c|}
\hline \multirow{2}{*}{$\begin{array}{l}\text { River (R) } \\
\text { Stream (lg) N/S }\end{array}$} & \multirow{2}{*}{ GPS } & \multicolumn{3}{|c|}{$\mathrm{N}^{\circ}$ fish in size class $(\mathrm{mm})$} & \multirow[t]{2}{*}{ Total No } \\
\hline & & -14.9 & -19.9 & -24.9 & \\
\hline R. Jufarís $\mathrm{N}$ & $62^{\circ} 00^{\prime} 27^{\prime} \mathrm{W} / 1^{\circ} 15^{\prime} 0^{\prime} \mathrm{S}$ & 0 & 4 & 1 & 5 \\
\hline R. Caurés / Lago Arraiá S & $62^{\circ} 25^{\prime} 7^{\prime} \mathrm{W} / 1^{\circ} 22^{\prime} 0^{\prime} \mathrm{S}$ & 2 & 1 & 2 & 5 \\
\hline R. Demini N & $63^{\circ} 0^{\prime} \mathrm{W} / 0^{\circ} 45^{\prime} \mathrm{S}$ & 2 & 0 & 3 & 5 \\
\hline R.Aracá N / lg. Maoaú & $62^{\circ} 53^{\prime} 13^{\prime \prime} \mathrm{W} / 0^{\circ} 23^{\prime} 31^{\prime} \mathrm{S}$ & 0 & 5 & 0 & 5 \\
\hline R. Cuiní S & $63^{\circ} 12^{\prime} \mathrm{W} / 0^{\circ} 45^{\prime} \mathrm{s}$ & 1 & 2 & 2 & 5 \\
\hline Ig. Mabarrá N & $64^{\circ} 37^{\prime} 19^{\prime \prime} \mathrm{W} / 0^{\circ} 29^{\prime} 50^{\prime \prime} \mathrm{S}$ & 1 & 4 & 0 & 5 \\
\hline R. Daraá N & $64^{\circ} 47^{\prime} 7^{\prime \prime} \mathrm{W} / 0^{\circ} 24^{\prime} 21^{\prime \prime} \mathrm{s}$ & 1 & 4 & 0 & 5 \\
\hline R. Urubaxí S / Ig. Trovão & $64^{\circ} 48^{\prime} 52^{\prime \prime} \mathrm{W} / 0^{\circ} 38^{\prime} 53^{\prime \prime} \mathrm{S}$ & 2 & 3 & 0 & 5 \\
\hline R. Aiuanã S / Igapó & $64^{\circ} 56^{\prime} 53^{\prime \prime} \mathrm{W} / 0^{\circ} 38^{\prime} 53^{\prime \prime} \mathrm{S}$ & 3 & 1 & 1 & 5 \\
\hline R. Marauiá * N / lg. Mariá & $65^{\circ} 9^{\prime} 37^{\prime \prime} \mathrm{W} / 0^{\circ} 22^{\prime} 41^{\prime \prime} \mathrm{s}$ & 0 & 4 & $2^{*}$ & 6 \\
\hline R. Negro / Ig. Arixaná N & $65^{\circ} 12^{\prime} 51^{\prime \prime} \mathrm{W} / 0^{\circ} 20^{\prime} 57^{\prime \prime} \mathrm{S}$ & 0 & 3 & 2 & 5 \\
\hline R. Negro / Ig. Jaradí N & $65^{\circ} 19^{\prime} 33^{\prime \prime} \mathrm{W} / 0^{\circ} 18^{\prime} 59^{\prime \prime} \mathrm{S}$ & 9 & 5 & 0 & 14 \\
\hline R. Negro / Ig. Bom Futuro N & $65^{\circ} 46^{\prime} 53^{\prime \prime} \mathrm{W} / 0^{\circ} 16^{\prime} 57^{\prime \prime} \mathrm{S}$ & 0 & 5 & 0 & 5 \\
\hline R. Tea ** S / Barragem Piracema & $65^{\circ} 59^{\prime} 31^{\prime \prime} \mathrm{W} / 0^{\circ} 37^{\prime} 50^{\prime \prime} \mathrm{S}$ & 2 & 0 & 3 & 5 \\
\hline TOTAL & 14 Sites & 23 & 41 & 16 & 80 \\
\hline
\end{tabular}




\section{ACTA AMAZONICA}

THE FOOD SPECTRUM OF THE CARDINAL - TETRA

(Paracheirodon axelrodi, CHARACIDAE) IN ITS NATURAL HABITAT. cut. The intestinal duct of $P$. axelrodi shows two well identifiable sections: the anterior, relatively voluminous ventricle or stomach, and, posteriorly, the relatively straight and short gut. Intestinal ducts hurt by the initial cut were examined in situ for the identification of their contents, so that particles would not get lost. Unhurt intestinal ducts were removed from the body cavity for better discrimination of their contents after being cut open. Dissection and analysis of the stomach and gut contents was done under the binocular microscope at magnification of 8-30x. As the stomach is relatively large and voluminous, and the gut short and narrow, the data refer essentially to "stomach content", but this includes also the usually few resource particles that could be recognized in the gut between the stomach and the anus.

Identification of stomach content: Ingested animals or plants were identified as such when either still entire (small animals and unicellular algaes) or from clearly recognizable fragments (plant tissues, head capsules of chironomid larvae and of hemimetabole insects, arthropod body appendages, carapace shells of micro-crustacea etc.). The stomach content was categorized as "detritus" then only, when it was found in sufficient quantities within the proper stomach, so that the conclusion of "detritus-feeding" appeared as a realistic proposition. For, evidently, the hind gut, filled with the digested material, practically always contained particles that could be listed as detritus. In addition, small quantities of detritus particles remain from prey guts, and/or enter the stomac when the fish are browsing for small prey over the surface of plants, litter and woods. Categorizing this kind of incidences as "detritus feeding" would be misleading as regards the feeding behavior of the cardinals. Quantification of ingestion of particular food organisms in \% of stomach volume (see Hyslop 1980 and Goulding et al 1988) was not attempted, because the basic objective was to ascertain the different types of food the cardinal was exploring. Occasionally, though, extraordinary accumulation of small resource organisms was specifically registered.

\section{RESULTS}

A list of the gut contents is presented in Table 2. Prey items not specified in this table are the following:

Micro-crustacea: Most Cladocera appeared to be of the small, almost spherical type Moinidae(?), however, larger daphnids and some macrothricids also appeared. The Copepoda were mostly the benthonic Harpacticidae.

Other insects include mostly Ephemeroptera nymphs, Ceratopogonidae and other Diptera larvae, smallest adult flies or pupae with already pigmented eyes (Dolichopodidae?), small Coleoptera larvae, Hemiptera nymphs (Naucoridae?) and chewed-up adult ants .This last item indicates that prey is also taken from the water surface, such as emerging adults (small flies) and insects that fell on - or were swept into - the water. Doubtless, some of unrecognizable insect fragments were the remains of ingested chironomid pupae or adults.

Other prey are small oligochaetes and mites (Oribatidae?). Uncertain is the suggestion of newly hatched shrimps on three occasions, and of a fish larva.

Mesofauna includes Rotifera (8 stomachs), usually several individuals per stomach, and of Thecamoebae ( 9 stomachs, including Difflugiidae, Nebeliidae and Arcellidae).

Eggs appeared generally to be of invertebrate origin, probably of Microcrustacea, but on two occasions vertebrate eggs (probably fish) were found.

Algae: The only algae recognized with certainty were the unicellular diatoms Navicularia and Pinnularia, but some green algae (Conjugatophyta and/or Chlamydomonas, or single cells of small Volvocaceae (?) were also present. The filamentous types were probably mostly Tribonema (Xanthophyceae), but cell wall structure also suggested some diatoms.

Detritus: animal detritus consisted of muscular, membraneous and other proteinous tissue not attributable to particular prey animals. Silvery membrane bits, black pigments and fish scales suggest that several cardinals were

Table 2 - Number $\left(\mathrm{N}^{\mathrm{o}}\right)$ of fish examined with their specified stomach contents: Clad. = Cladocera; Cop = Copepoda; $\mathrm{a}=$ mostly small $(<2 \mathrm{~mm})$ scraping larvae of the sub-family Chiromininae; $b=$ larger $(>2 \mathrm{~mm})$ larvae of the predatory Tanypodinae (Pentaneura?). Further specifications of stomach contents see p. 71 includes a single fish of $28 \mathrm{~mm}$ with algae and detritus in its stomach (see Table 1 ). ! Horizontal lines do not add up to their total $\mathrm{N}^{\circ}$ and $\%$, because single stomachs contain several types of prey and/or detritus, (see p.71) .

\begin{tabular}{|c|c|c|c|c|c|c|c|c|c|c|c|c|c|c|c|}
\hline \multicolumn{16}{|c|}{ Number of fish with specified stomach contents } \\
\hline \multirow{2}{*}{$\begin{array}{l}\text { Fish Size } \\
\text { mm }\end{array}$} & \multirow[t]{2}{*}{$N^{\circ}$ of fish } & \multicolumn{3}{|c|}{ Micro-Crustacea } & \multicolumn{3}{|c|}{$\begin{array}{l}\text { Chironomidae } \\
\text { (Díptera) }\end{array}$} & \multirow{2}{*}{$\begin{array}{c}\text { Other } \\
\text { - insects }\end{array}$} & \multirow{2}{*}{$\begin{array}{l}\text { Other } \\
\text { prey }\end{array}$} & \multirow{2}{*}{$\begin{array}{l}\text { Meso- } \\
\text { fauna }\end{array}$} & \multirow{2}{*}{ Eggs } & \multirow{2}{*}{ Algae } & \multicolumn{3}{|c|}{ Detritus. } \\
\hline & & Total & Clad & Cop & Total & $a$ & b & & & & & & Total & Anim. & Veget. \\
\hline $11-14.9$ & $23 !$ & 7 & 7 & 1 & 8 & 8 & 0 & 1 & 1 & 11 & 6 & 5 & 14 & 6 & 6 \\
\hline $15-19.9$ & $41 !$ & 21 & 19 & 3 & 16 & 15 & 4 & 10 & 3 & 4 & 2 & 3 & 14 & 11 & 3 \\
\hline $20-24.0$ & *16! & 10 & 8 & 3 & 11 & 11 & 1 & 3 & 2 & 3 & 2 & 2 & 4 & 3 & 1 \\
\hline$\%$ & $\begin{array}{l}80 ! \\
100 !\end{array}$ & $\begin{array}{c}38 \\
47.5\end{array}$ & & & $\begin{array}{c}35 \\
43.8\end{array}$ & & & $\begin{array}{c}14 \\
17.5\end{array}$ & $\begin{array}{c}6 \\
7.5\end{array}$ & $\begin{array}{c}18 \\
22.5\end{array}$ & $\begin{array}{c}10 \\
12.5\end{array}$ & $\begin{array}{c}10 \\
12.5\end{array}$ & $\begin{array}{c}32 \\
40.0\end{array}$ & & \\
\hline
\end{tabular}




\section{ACTA \\ AMAZONICA}

THE FOOD SPECTRUM OF THE CARDINAL - TETRA

(Paracheirodon axelrodi, CHARACIDAE) IN ITS NATURAL HABITAT. feeding on larger, dead fish. Other tissues apperead to be the remnants of larger dipteran larvae. Vegetal detritus includes mostly plant fibres, bits of bark and of leaf litter with fragments of the decomposition fungi, the Hyphomycetes, and probably, bits of fruits. In some cases the bark detritus was intensely orange coloured; this suggests the presence of iron $\left(\mathrm{Fe}^{+++}\right)$- processing bacteria (Chlamydobacteriales).

As a last item parasites should be mentioned. In one fish each of five rivers, a nematode was found in either the coelome or the stomach; this could not be decided, because the stomach, after being opened, was not removed from the body cavity. Parasitism by nematods would thus amount to $6.3 \%$ of the 80 dissected fish. The small number of fish dissected does not allow to draw general conclusions as regards the rate of parasitism, except for the observation that nematod parasitism does occur in the species Paracheirodon axelrodi.

\section{DISCUSSION AND CONCLUSIONS}

The general picture (Tab.2) is the following: A total of 163 resource incidences were listed for 80 consumer fish, resource incidence being defined as resource type found within a digestive tract. Thus, on the average, the fish contained 2.03 types of resource in their stomach/intestine. One stomach was completely empty, and in one other, animal remains were completely absent. Animal resource incidence, including animal detritus, totalled 141, while algae and plant detritus were registered in 20 stomachs only. Evidently, cardinals are primarily predators of small, invertebrate prey, mostly of micro-crustracea and of chironomid larvae. That the presence of these organisms in the guts is not merely a side-effect of periphyton scraping is shown by two facts: one is the relative rarity of algae in stomachs (in 12.5\%), and the second is the large number of similar prey that are often found within a single stomach. Thus, on several occasions the lab protocol reads "stomach stuffed full of small Cladocera", for instance twice more than 50 , and once more than 200 ! Frequently, several chironomid larvae were found in the same stomach, and single large prey items, such as ephemeropteran nymphs, are probably picked up by choice. These findings differ essentially from the results reported by Goulding et al (1988): in the ventricles of 23 dissected cardinals, only detritus was registered. This discrepancy may be due to the methods of food identification: In the present study, only fish with recognizable detritus in their stomachs were categorized

It is notable that the smallest category of fish seemed to show preference for mesofauna (11 fish) and egg (6 fish) predation. The combined frequency is significantly higher than in larger fish $\left(\mathrm{P}<0.05 ; \mathrm{X}^{2}\right.$ test $)$. The same may be true for the alga incidence in the smallest fish class $(5 / 23$ fish. $\mathrm{P}<0.15)$. In these five cases the algae were classified as Chlorophyceace or Xanthophyceae, which may be more attractive than diatoms with their glass-like silica cell walls.
Eggs, sessile rotifers, Thecamoebae and algae are easier to ingest than larger, free-swimming prey; this might explain the preference of these latter items by smaller fish.

The prey categories shown in Tab.2 are sufficiently general to suppose that they are present in any stream and river of the Rio Negro Basin. However, gut content and phase of digestion were sometimes strikingly concordant within - and discordant between - groups of different rivers. As the 5 inidividuals separated for dissection were sometimes derived from the same net sample, this scenario confirms that the cardinal moves and feeds in social groups or schools, as is observed in nature. For instance, all five fish $(15-19 \mathrm{~mm}$ long) of the Rio Aracá had larger numbers of small cladocera in their stomachs, beside either chironomid or other small insect larvae. In the sample of the Rio Urubaxí (12-17.5mm standard length), 4 had more or less empty stomachs except for a few chitin bits, and one stomach contained a fresh, adult ant. The cardinal thus shows similar feeding habitats as other small characiforms of the Rio Negro Basin (Leite and Araújo-Lima 2002; Goulding et al 1988). The internal anatomy of $P$. axelrod $i$ agrees with a predatory mode of feeding in teleost fishes: The stomach is voluminous, and the gut is short, at best twice the length of the body cavity (Ziswiler 1976).

More often than not, the prey appears to be triturated and compacted between the folds of the stomach. Without careful examination, this may result in the categorization of "animal detritus". On other occasions, the tissues of still entire prey larvae of Ephemeroptera and Diptera were transparent, as if the cell contents had been liquified; and twice, a chironomid larva was found in the gut with only its head capsule and the entire body epidermis in the form an "empty stocking". Such consecutive stages of digestion with following fragmentation renders food identification increasingly difficult, and the temptation is, to classify eventually unidentifyable particles of arthropod chitin or of plant fibres as "detritus". In fact, only 10 cardinals had sufficient plant detritus in their stomachs to be categorized as "plant detritus feeding". Choice of particular plant matter seems therefore to occur, particularly in the smaller fish.

The cardinals being essentially predators raises the question of prey availability in the extremely mineral -poor waters of the Rio Negro Basin (Sioli 1984). Géry (1977) suggested that the cardinal might be limited to a single annual generation because of food scarcity, while in captivity, the fish may breed repeatedly. Of the 80 fish dissected in this study, only 4 were recognized as females, and one only was noted with relatively large oocytes (ca $0.8 \mathrm{~mm} \mathrm{Dm})$. Even this female $(24 \mathrm{~mm})$ was small as compared to the normal, adult size indicated by Axelrod $(1990 ; 50 \mathrm{~mm})$. The relatively small size of all fish collected, and the inconspicuous states of their gonads, agrees with the suggestion of a single generation in an annual life cycle. Geisler and Annibal (1984) also comment on the difference of the cardinals' size and they, too, conclude that resource scarcity is the reason for reduced size and reproduction in nature. If, however, the trophic structure of 


\section{ACTA \\ AMAZONICA}

THE FOOD SPECTRUM OF THE CARDINAL - TETRA

(Paracheirodon axelrodi, CHARACIDAE) IN ITS NATURAL HABITAT. the benthic community in the middle Rio Negro region is essentially similar to what is known from the Manaus region, food shortage per se is hardly the cause of reduced growth of the cardinal. These foodwebs start essentially with litter decomposition by aquatic fungi (Hyphomycetes, Baerlocher \& Kendrick, 1981) which are ingested by a larger variety of small (mesofaunal) organisms associated with submerged litter, principally by chironomid larvae. Thus, single litter leaves, submerged between 2 days and 4 months, are occupied, on the average, by 7-36 chironomid larvae, beside small oligochaetes, microcrustacea, rotifera etc (Walker 1986, 1988,1998). Total standing stock of prey per potential predator, predators including fish, shrimps and odonata larvae, amounts to some 300 prey per predator, (this while predation is in full operation!). It is reasonable to assume that the submerged litter, and other wood and plant debris, is colonized by a similar community of mesofaunal organisms in the middle region of the Rio Negro Basin, although, of course, this needs confirmation by quantitative sampling and analysis. If this should prove to be the case, resource density would not be the limiting factor for growth and reproduction. It may be suggested, though, that the annual inundation cycles, which induce the migration and spawning period during rising waters (February to April; Geisler and Annibal 1984), do not allow the fish to invest sufficient time and energy for building up the necessary quantities of proteins for continued growth and reproduction. During the migration over large distances, twice a year and in partly turbulent waters, the cardinals are deprived of permanent home ranges with known niches of food supply and of refuge. Moreover, they are exposed to the incessant threat by larger predatory fish. These unfavourable migration phases may consume an unduly large share of energy. This would mean that stress and locomotion, and perhaps reduced feeding time, are the limiting factors for growth and reproduction of the cardinal in its natural habitat.

\section{ACKNOWLEDGEMENTS}

This research was financed by the "Project Piaba" (UFAM and INPA, Manaus).

I thank Dr. P. Petry for providing the fish specimens for dissection.

\section{LITERATURE CITED}

AXELROD, H. R. 1990. Atlas de peixes de aquário de agua doce. 3. edtn. T.F.H. Publications, Neptune City, NY.

BÄRLOCHER, F.; Kendrick, B. 1981. Role of aquatic hyphomycetes in the thropic structure of streams. In: Wicklow, D. T. and Carrol, G. C. ed. The fungal community. Marcel Dekker, New York.

BAYLEY, P. B.; Petrere Jr. M. 1989. Amazon fisheries: assessment methods, current status and management options, in Dodge, D. P. ed. Proceedings of the International Large River Symposium. Canadian Fisheries and Aquatic Sciences Special Publications 106: 385-398.
Chao, N. L. 2001. The fishery diversity and conservation of ornamental fishes in the Rio Negro Basin, Brasil: A review of Project Piaba (1989 - 1999). In: Chao, N. L.; Petry, P.; Prang,G.; Sonnenschein L.; Tlusty M.T. eds: Conservation and management of ornamental fish resources of the Rio Negro Basin, Amazonia Brasil - Project Piaba. Editora da Universidade do Amazonas, Manaus. pp.161-204.

Geisler, R.; Annibal, S. R. 1984. Oekologie des Cardinal Tetra Paracheirodon axelrodi (Pisces, Characoidea) im Stromgebiet des Rio Negro/Brasilien, sowie zuchtrelevante Faktoren. Amazoniana, 9: 53-86.

Géry, J. 1977. Characoids of the world. T. F. H. Publ. Inc. Ltd. Neptun City, NY, 672 pp.

Goulding, M.; Leal-Carvalho, M.; Ferreira, E.G. 1988. Rio Negro, rich life in poor water: Amazonian diversity and foodchain ecology as seen through fish communities. SPB Academic Publishing, The Hague. 172 pp.

Hyslop, E. J. 1980. Stomac contents analysis - a review of methods and their application. J. Fish Biol., 17: 411 - 429.

Leite, R. G.; Araújo-Lima, C. A. 2002. Feeding of the Brycon cephalus, Triportheus eloganthus and Semaprochilodus insignis (Ostheichthyes, Characiformes) larvae in Solimoes/Amazonas river and floodplain areas. Acta Amazonica, 32(3): - 516.

Sioli, H.(ed) 1984. The Amazon. Dr. W. Junk Publ. Dordrecht, 763 pp.

Walker. I. 1986. Experiments on colononization of small water bodies by Culicidae and Chironomidae as a function of decomposing plant substrates and their implications for natural Amazonian ecoystems. Amazoniana, 10:113-125.

Walker, I. 1987. The biology of streams as part of Amazonian forest ecology. Experientia, 43:279-287.

Walker. I. 1988. Study of benthic micro-faunal colonization of submerged litter leaves in the Central Amazonian blackwater stream Tarumã-Mirim. Acta Limnol. Brasil, 2: 623-648.

Walker, I. 1998. Population dynamics of Chironomidae (Diptera) in the Central Amazonian blackwater river Tarumã-Mirim (Amazonas, Brazil). Oecologia Brasiliensis, 5: 235-252.

Weitzman, S. H.; Fink, W. L. 1987. Neon Tetra relationships and phylogenetic systematics. Tropical Fish Hobbiist, 36: 72-77.

Ziswiler, V. 1976. Spezielle Zoologie: Wirbeltiere. Georg Thieme Verlag, Stuttgart, Vol.1, 278 pp.

RECEBIDO EM 31/01/2003

ACEITO EM 17/12/2003 
